SANDIA REPORT

SAND 2010-0241

Unlimited Release

Printed February 2010

\title{
Sandia National Laboratories, California Sewer System Management Plan
}

\section{February 2010}

Prepared by

Sandia National Laboratories

Livermore, California 94550

Sandia is a multiprogram laboratory operated by Sandia Corporation,

a Lockheed Martin Company, for the United States Department of Energy's

National Nuclear Security Administration under Contract DE-AC04-94AL85000.

Approved for public release; further dissemination unlimited.

\section{G. Sandia National Laboratories}
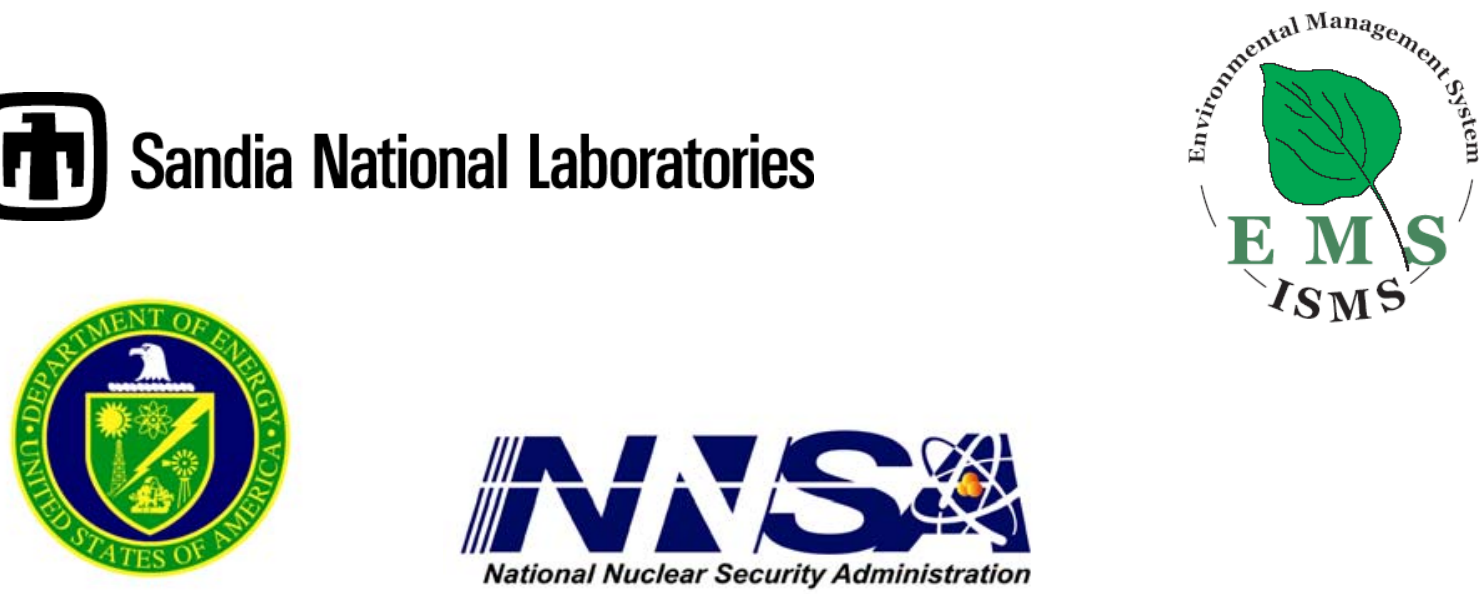
Issued by Sandia National Laboratories, operated for the United States Department of Energy by Sandia Corporation.

NOTICE: This report was prepared as an account of work sponsored by an agency of the United States Government. Neither the United States Government, nor any agency thereof, nor any of their employees, nor any of their contractors, subcontractors, or their employees, make any warranty, express or implied, or assume any legal liability or responsibility for the accuracy, completeness, or usefulness of any information, apparatus, product, or process disclosed, or represent that its use would not infringe privately owned rights. Reference herein to any specific commercial product, process, or service by trade name, trademark, manufacturer, or otherwise, does not necessarily constitute or imply its endorsement, recommendation, or favoring by the United States Government, any agency thereof, or any of their contractors or subcontractors. The views and opinions expressed herein do not necessarily state or reflect those of the United States Government, any agency thereof, or any of their contractors.

Printed in the United States of America. This report has been reproduced directly from the best available copy.

Available to DOE and DOE contractors from

U.S. Department of Energy

Office of Scientific and Technical Information

P.O. Box 62

Oak Ridge, TN 37831

Telephone: $\quad$ (865) 576-8401

Facsimile: (865) 576-5728

E-Mail: $\quad$ reports@adonis.osti.gov

Online ordering: http://www.doe.gov/bridge

Available to the public from

U.S. Department of Commerce

National Technical Information Service

5285 Port Royal Road

Springfield, VA 22161

Telephone: (800) 553-6847

Facsimile: (703) 605-6900

E-Mail: $\quad$ orders@ntis.fedworld.gov

Online order: $\quad \underline{\text { http://www.ntis.gov/ordering.htm }}$
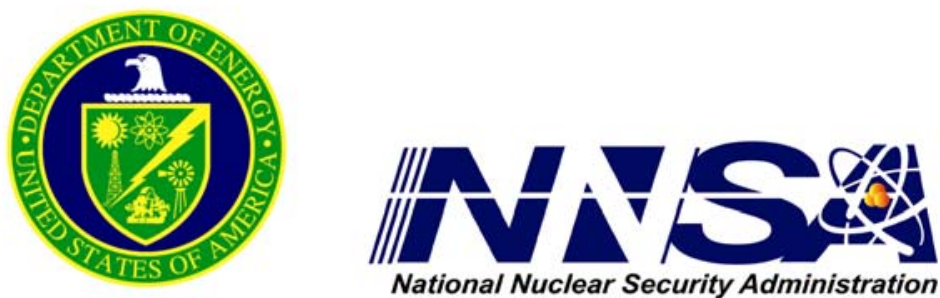
SAND 2010-0241

Unlimited Release

February 2010

\title{
Sandia National Laboratories, California Sewer System Management Plan
}

\author{
Robert C. Holland \\ Environmental Management Department \\ Sandia National Laboratories, California
}

\begin{abstract}
A Sewer System Management Plan (SSMP) is required by the State Water Resources Control Board (SWRCB) Order No. 2006-0003-DWQ Statewide General Waste Discharge Requirements (WDR) for Sanitary Sewer Systems (General Permit). DOE, National Nuclear Security Administration (NNSA), Sandia Site Office has filed a Notice of Intent to be covered under this General Permit. The General Permit requires a proactive approach to reduce the number and frequency of sanitary sewer overflows (SSOs) within the State. SSMPs must include provisions to provide proper and efficient management, operation, and maintenance of sanitary sewer systems and must contain a spill response plan. Elements of this Plan are under development in accordance with the SWRCB's schedule.
\end{abstract}




\section{Contents}

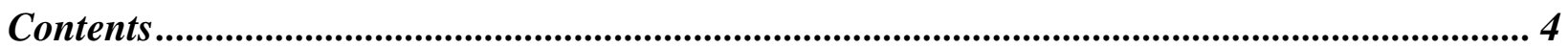

Figures............................................................................................................................................... 5

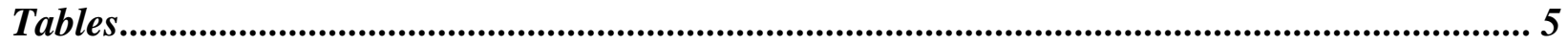

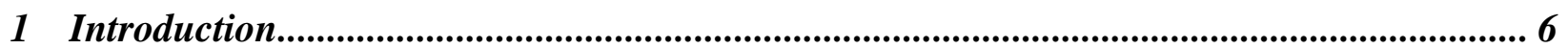

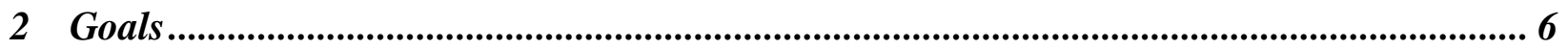

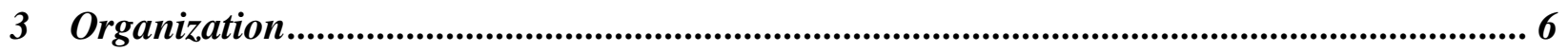

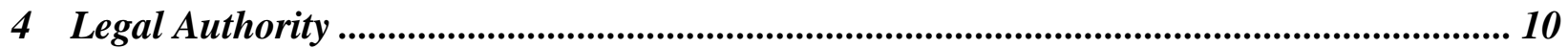

5 Operation and Maintenance Program .................................................................................... 10

5.1 Routine Preventative Maintenance......................................................................................................11

5.2 Scheduled Inspections and Condition Assessment ......................................................................... 12

5.3 Contingency Equipment and Replacement Inventories ............................................................13

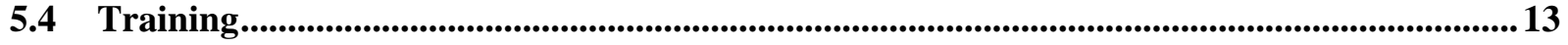

5.5 Rehabilitation and Replacement Plan ......................................................................................... 14

6 Overflow Emergency Response Program........................................................................... 17

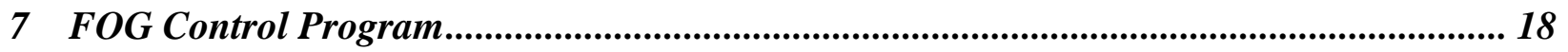

8 Design and Performance Provisions ........................................................................ 18

9 System Evaluation and Capacity Assurance Plan .................................................................... 18

10 Monitoring and Program Modifications................................................................................. 18

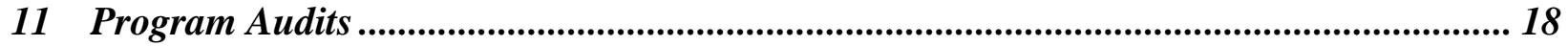

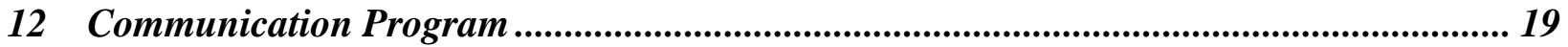

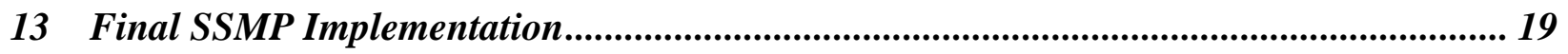

14 Appendix A Notice of Intent, LRO Form and Data Submitter Form ................................. 20

15 Appendix B Sewer System Map .................................................................................... 21

16 Appendix C Training Matrices for SNL/CA Plumbing Staff ............................................... 22

Note: Elements of this Plan are under development in accordance with the State Water Quality Control Board's schedule. 


\section{Figures}

Figure 3-1. Organization Chart (Sewer System) ......................................................... 9

\section{Tables}

Table 5-1. Routine Sewer Maintenance........................................................................... 11

Table 5-2. Basic Corporate Required Training for Plumbing Staff ........................................... 14

Table 5-3 Sewer Rehabilitation and Improvement Plan ........................................................... 15 


\section{Introduction}

The U.S. Department of Energy (DOE) National Nuclear Security Administration (NNSA) Sandia Site Office filed a Notice of Intent (NOI) for the SNL/CA facility to be covered under the State Water Resources Control Board (SWRCB) Order No. 2006-0003-DWQ Statewide General Waste Discharge Requirements (WDR) for Sanitary Sewer Systems (General Permit) at the direction of the SWRCB staff (see Appendix A). Provision D.11 of the General Permit requires the development and implementation of a written Sewer System Management Plan (SSMP). This SSMP is prepared according to the mandatory elements required by Provision D.13 and the schedule for a population less than 2,500 as outlined in Provision D.15.

\section{Goals}

This SSMP delineates the following SNL/CA goals:

- To properly manage, operate, and maintain all parts of the sanitary sewer system.

- To provide a safe working environment for DOE and SNL/CA employees.

- To provide adequate capacity to convey peak flows to the City of Livermore's sanitary sewer collection system via the Lawrence Livermore National Security's sanitary sewer system.

- To minimize the frequency and duration of SSOs.

- To mitigate the impact of SSOs on public health and the environment.

- To respond quickly to notifications of SSOs or other collection system problems.

- To collect complete and accurate information regarding SSOs for reporting to the appropriate regulatory agencies.

- To provide SNL/CA maintenance employees with the tools and training needed to perform their work effectively and achieve the site's goals.

- To document system Operation and Maintenance activities using tools that support efficient utilization of staff and resources, and which provide a means for long-term assessment of trends and effectiveness.

\section{Organization}

Sandia is a multiprogram laboratory with primary facilities in New Mexico and California operated by Sandia Corporation, a Lockheed Martin Company, for DOE NNSA. The site, the buildings, and the equipment are owned by the government; while Sandia Corporation, a Lockheed Martin Company, operates the laboratory for the DOE NNSA. The DOE/Sandia Site Office oversees the operations at the site, using Sandia Corporation as a management and operating contractor. 
The Sandia Site Office Manager is designated by DOE as the authorized representative. The Sandia Site Office Manager, as the Legally Responsible Official (LRO), has designated the Sandia Site Office Water Quality Program Manager as an additional LRO and the SNL/CA Environmental Monitoring Program Lead as the Data Submitter (see Appendix A for LRO and Data Submitter forms). The Environmental Monitoring Program Lead ensures regulatory compliance for the wastewater, stormwater and groundwater programs on site. The Sandia Site Office Water Quality Program Manager has oversight responsibility for the SNL/CA Environmental Management Department’s Environmental Monitoring Program.

SNL/CA is a controlled site with a 24 hour security force. Any collection system problems can be reported through the Environmental, Safety and Health (ES\&H) hotline (continuously manned), the Maintenance Trouble Line or the security Central Alarm Station (manned 24 hours a day). The Environmental Monitoring Program Lead is informed of any problems or releases from the sanitary sewer system. The Environmental Monitoring Program Lead is responsible for informing the Sandia Site Office Water Quality Program Manager of any SSOs that need to be reported to the State Board.

An organization chart is presented in Figure 3-1. Roles and responsibilities of key personnel involved in the wastewater collection system are as follows:

Environmental Monitoring Program Lead: Responsible for development, updating and coordinating implementation between departments of the SSMP. Responsible for relating SSO reporting information to the Sandia Site Office Water Quality Program Manager. Staff liaison with the SWRCB, City of Livermore Water Reclamation Plant and other appropriate regulatory agencies. Responsible for reporting SSOs in the State's SSO database. Designated as a Data Submitter.

Sandia Site Office Water Quality Program Manager: Reviews all SSO reporting information from the Environmental Monitoring Program Lead. As a designated additional LRO by the Sandia Site Office Manager has responsibility of certifying the data entry and reporting entered by the designated Data Submitter.

Sandia Site Office Manager: The authorized representative and designated LRO has oversight of the Sandia Site Office Water Quality Program Manager. As the designated LRO has designated an additional LRO and Data Submitter.

Maintenance Engineering Department Manager: Manages collection system field operations and maintenance activities and collection system data management. Provides data to Environmental Monitoring Program Lead, prepares and implements contingency plans, coordinates site response to collection system emergencies or problems, coordinates investigations and follow-up of blockages and SSOs.

Maintenance Crew: Conducts collection system corrective and preventive maintenance activities, including emergency response for blockages and SSOs. When directed, coordinates with vendors 
and outside contractors for equipment and services. Note: Waste Management staff trained in spill response are also available to respond to SSOs.

Planning and Construction Management Department Manager: Overall is responsible for design of Capital Improvements Projects. Reviews and develops SNL/CA's standard specifications for sewer construction. Conducts collection system capacity analysis and develops recommendations and budgets for capital improvements projects. Provides construction management inspection services.

Project Engineering and Operations Manager: Responsible for implementing Capital Improvement Projects and construction oversight. Responsible for maintaining sanitary sewer system maps.

SNL/CA has its own incident reporting and tracking procedures. A sanitary sewer system issue may fall under: Injury/Illness/Property Damage Investigation and Reporting Operating Procedure 471105, Nonconformance Item Identification and Tracking Operating Procedure 471125, Nonconformance Reporting, Form Logging and Tracking Operating Procedure 471411 or Reporting Wastewater Noncompliance Incidents Operating Procedure 471608. 
Figure 3-1. Organization Chart (Sewer System)

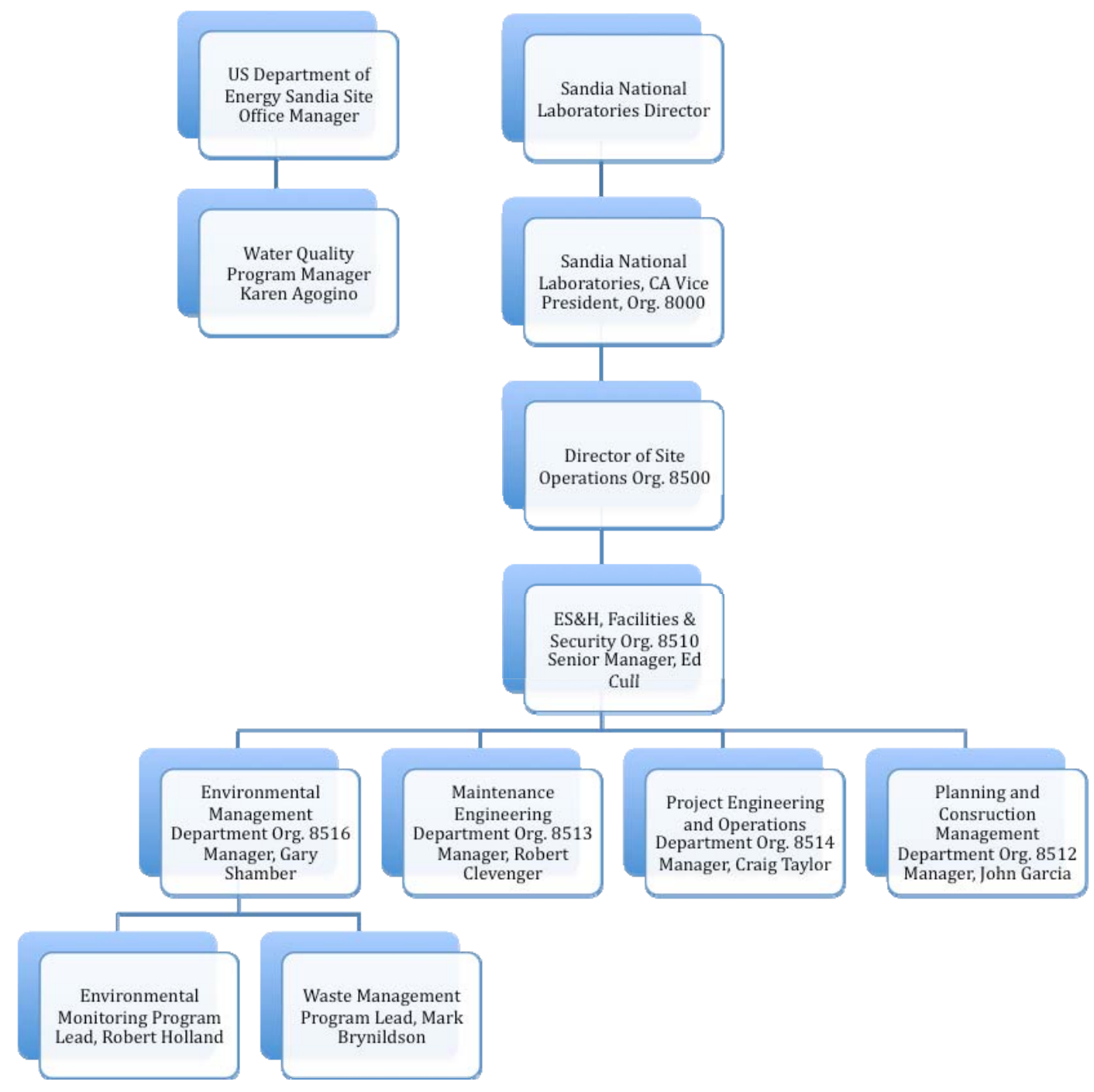




\section{Legal Authority}

Requirements related to legal authority in the SWRCB's Statewide General Order 2006-003DWQ are as follows:

Each Enrollee must demonstrate, through sanitary sewer system use ordinances, service agreements, or other legally binding procedures, that it possesses the necessary legal authority to:

(a) Prevent illicit discharges into its sanitary sewer system (examples may include I/I, stormwater, chemical dumping, unauthorized debris and cut roots, etc.);

(b) Require that sewers and connections be properly designed and constructed;

(c) Ensure access for maintenance, inspection, or repairs for portions of the lateral owned or maintained by the Public Agency;

(d) Limit the discharge of fats, oils, and grease and other debris that may cause blockages, and

(e) Enforce any violation of its sewer ordinances.

SNL/CA is a government owned/contractor operated facility. The site, the buildings, and the equipment are owned by the government; while Sandia Corporation, a Lockheed Martin Company, operates the facility for the Department of Energy's National Nuclear Security Administration (NNSA). The NNSA/Sandia Site Office oversees the operations at the site, using Sandia Corporation as a management and operating contractor.

SNL/CA operates in compliance with the letter and spirit of applicable federal, state, and local environmental laws and regulations. Additionally, as a Department of Energy (DOE) facility, the site is subject to DOE directives (DOE Orders), and to presidential executive orders. DOE Orders 450.1, 5400.5, and DOE/EH-0173T, establish environmental protection program requirements, authorities, and responsibilities. These Orders stipulate that all DOE facilities comply with Federal, State, and local environmental protection laws and regulations, and best management practices.

SNL/CA has the authority to perform all of the prevention, maintenance and enforcement activities required in the State General Permit through DOE oversight as the owner of the sanitary sewer system, buildings and equipment and employer of site personnel.

\section{Operation and Maintenance Program}

Detailed sanitary sewer system and storm drain system maps are maintained in electronic form (AutoCad) by the SNL/CA Project Engineering and Operations Department (8514). Maps are included in Appendix B. The maps show the sanitary sewer system onsite including all gravity line segments and manholes, pumping facilities, pressure pipes and valves, and stormwater conveyance system.

The sanitary sewer map was recently reviewed and updated after a sanitary sewer line investigation performed in August and September 2008. A systematic review and update of map occurred during the extensive copper investigation activities that began in August 2008. The 
contractor prepared a Sanitary Sewer Evaluation Report (URS May 5, 2009) based on the investigations. The map will be reviewed and updated after each new construction project onsite.

\subsection{Routine Preventative Maintenance}

SNL/CA operates a prioritized preventative maintenance (PM) program designed to maintain the integrity of the system, reduce the frequency of SSOs, and reduce I/I. The program uses the MAXIMO (commercially available software) database as the primary data management tool, in conjunction with inspections and other management tools. PM activities are prioritized based on results from historic PM and corrective maintenance activities. Prioritization is an ongoing process, with PM schedules updated based on recommendations contained in inspection reports.

PM activities including flushing sewer lines and pump maintenance. MAXIMO issues a monthly schedule that specifies PM activities for that month. Example schedules are included in Appendix B. The location of the PM is specified in terms of structure ID or sewer line segment identified by upstream and downstream manholes.

Lateral lines and problem areas are flushed on a monthly or semi-annual basis. The lateral lines include critical branch lines connecting to the main sanitary sewer system, such as lateral lines joining building sewer lines from toilets and sinks, and industrial waste lines from labs and mechanical equipment. Problem areas are defined as an area that has had a sewer backup, blockage, line sags or shallow slope. The flushing involves pumping large quantity of potable water at standard pressure into the sewer line through a cleanout or a drain inlet. The flushing shall run for 15 minutes (or approximately 2000 gallons). The flushing operations are logged and records are kept for five years. The following areas are identified for flushing PM activities:

\begin{tabular}{|l|l|}
\hline Line Segment & Frequency \\
\hline B905 lateral line. & Semi-Annual \\
\hline B906 Lab waste lines. & Semi-Annual \\
\hline Lateral line in front of B928. & Semi-Annual \\
\hline Lateral line from Redwood Complex. & Semi-Annual \\
\hline B910 Lateral line. & Semi-Annual \\
\hline B943 Lateral line. & Semi-Annual \\
\hline Lateral line from M50/M51. & Semi-Annual \\
\hline Line from MH25. & Monthly \\
\hline Line from MH32. & Semi-Annual \\
\hline Line from MH46. & Semi-Annual \\
\hline Line from MH35. & Monthly \\
\hline Line from MH43. & Semi-Annual \\
\hline
\end{tabular}

Table 5-1. Routine Sewer Maintenance

These areas were identified during the extensive copper investigation and based on the URS findings in the Sanitary Sewer Evaluation Report (May 5, 2009). 


\subsection{Scheduled Inspections and Condition Assessment}

SNL/CA's system for inspections and condition assessment is closely integrated into the preventative maintenance program described in the previous section. The system is designed to proactively identify problem areas and structural deficiencies, and to take appropriate actions before these problems result in blockages, SSOs, or structural failures. Problem areas are identified using a variety of tools, including visual inspection, video inspections and flow monitoring.

A physical survey/visual inspection of all sewer system components including manholes, exposed sewer pipes, pump stations (B914 Equipment Room, B912 Basement, B955 and B962 Basement), cooling tower basins, sink traps, LEC systems (906, 916, 968 and 941 LECS) and sumps, is conducted annually. The physical survey/visual inspection identifies defects related to safety, defects related to structural and mechanical stability and operation, accumulated sediment and debris deposits, visible flow bottlenecks, and any evidence of present or prior surcharging or overflows. A log of physical survey/visual inspection shall record the inspection date, name of inspector, and observation notes. These records will be retained for 5 years.

Problem areas are documented and forwarded to Organization 8512 Facilities Planning \& Construction Management, Organization 8513 Maintenance Engineering, or Organization 8514 Project Engineering and Operations as appropriate for corrective action.

Sewer line cleaning and CCTV inspection for all sewer lines that are 6 inches in diameter or greater, and sewer lines that are associated with chronic basement flooding or chronic maintenance areas, will be conducted every three years. The sewer line cleaning and CCTV inspection will usually be performed by a specialty sewer maintenance contractor. The sewer lines shall be cleaned using high pressure jetting prior to an internal pipe inspection by CCTV. For severely clogged sewer lines that could not be unclogged by high pressure jetting, a machine-driven root cutter or other mechanical device may be used to clear the blockage. The CCTV inspection shall include audio/visual documentation, with a written summary to include the location of roots intrusions, defective joints, defective pipes, sewer line depressions, breaks in lateral connections, and grease and sediment accumulations. The CCTV Inspection report will be documented in both written and digital formats. The inspection records will be retained for five years. A copy of the report will be sent to Organization 8512, Facilities Planning \& Construction Management.

Organization 8512 Facilities Planning \& Construction Management will use the PM and inspection logs to plan, budget and prioritize corrective actions. In prioritizing the correction of structural deficiencies, a number of factors in addition to the specific structural condition must also be considered, including: budgeting and timing considerations vis-à-vis other SNL/CA projects; grouping of corrective actions into coherent projects that are large enough to attract highly qualified contractors and maximize the benefit attained for the funds expended; ability to maintain service during construction, including consideration of reasonable "worst-case" flow scenarios; and environmental and customer impact issues. 


\subsection{Contingency Equipment and Replacement Inventories}

Emergency equipment includes a variety of trailer mounted portable generators (up to $460 \mathrm{kw}$ ), portable pumps (up to 12 inch), spare electric submersible pumps that are direct replacements for the pumps used in many of the smaller collection system pump stations, piping and hoses, samplers, and other equipment. An emergency response trailer is equipped with most of the small items normally needed in an emergency response situation. In addition, SNL/CA has several pieces of equipment that are available to be utilized in the event of an emergency, such as back-hoes and a Vactron ${ }^{\mathrm{TM}}$.

For the collection system, repair parts consist primarily of repair clamps in those sizes needed to match SNL/CA lines. SNL/CA also has a contract with a supply company that is able to provide any needed parts that SNL/CA may not have available. These parts are available 7 days a week, 24-hours a day.

The following table is a general list of the equipment available on-site for emergency sewer repairs.

\begin{tabular}{|c|c|}
\hline Equipment & Inventory \\
\hline Sewer sump pump, 3/4 HP & 1 \\
\hline By-pass Hose & $400 \mathrm{ft}$. \\
\hline Balloons 2 inch to 8 inch & 6 \\
\hline Repair clamps 2 inch to 8 inch & 4 \\
\hline Sewer Cables & 2 \\
\hline No Hub bands 4 inch to 8 inch & 6 \\
\hline 10 mil tape & 4 \\
\hline Emergency lights and generators & rolls \\
\hline
\end{tabular}

\subsection{Training}

SNL/CA's training activities fall into two categories, safety and job skills. The two are closely related insofar as safety is of prime consideration in performance of any job activity. Annual safety training is conducted by SNL/CA staff, outside consultants or through corporate web based training (TEDS) in the areas listed below in Table 5-3. SNL/CA has three plumbers onsite. Plumbers are required to be certified Journeyman plumbers. The Training and Certification held by the plumbers are shown in Appendix C.

Local Code Title

\begin{tabular}{ll}
\hline CI100 & ANNUAL COUNTERINTELLIGENCE TRAINING \\
ESH100 & ES\&H AWARENESS \\
COM100 & CYBER SECURITY AWARENESS TRAINING
\end{tabular}

ENV112CA HAZARDOUS WASTE \& ENVIRONMENTAL MANAGEMENT 


$\begin{array}{ll} & \text { TRAINING (CA) } \\ \text { NSE100 } & \text { OCCUPATIONAL NOISE } \\ \text { RSP215 } & \text { AIR-PURIFYING RESPIRATORY PROTECTION } \\ \text { HAZ101 } & \text { EMPLOYEE BASIC HAZCOM } \\ \text { HAZ103 } & \text { SITE-SPECIFIC HAZCOM } \\ \text { CNF105 } & \text { CONFINED SPACE AWARENESS - CA } \\ \text { CNF107 } & \text { CONFINED SPACE ENTRY } \\ \text { FRP106CA } & \text { HANDS ON FIRE EXTINGUISHER TRAINING - 3 YEAR } \\ \text { PRS150 } & \text { PRESSURE SAFETY ORIENTATION } \\ \text { LTO210 } & \text { LOCKOUT/TAGOUT FOR AUTHORIZED WORKERS } \\ \text { ELC105 } & \text { BASIC ELECTRICAL SFTY (GREATER THAN 50 VOLTS) } \\ \text { FPP105CA } & \text { FALL PROTECTION AND PREVENTION } \\ \text { PROP101 } & \text { PROPERTY BASICS } \\ \text { MCH111 } & \text { MACHINE SHOP SAFETY }\end{array}$

Table 5-2. Basic Corporate Required Training for Plumbing Staff

Job skills training includes reviewing technical work documents (e.g. Operating Procedures) and job specific training conducted by SNL/CA staff (e.g. spill response).

\subsection{Rehabilitation and Replacement Plan}

Based upon the Sanitary Sewer Evaluation Report (URS May 5, 2009), SNL/CA has developed a schedule for replacement or repair of sections of the sanitary sewer. Table 5-2 shows the priority for completing these items. Additions to this table will be made after annual sewer system inspections or triennial CCTV inspections (see section 5.2) as necessary. 
Table 5-3 Sewer Rehabilitation and Improvement Plan

\begin{tabular}{|c|c|c|c|c|}
\hline \multicolumn{5}{|c|}{$\begin{array}{l}\text { SANITARY SEWER SYSTEM 10-YEAR CAPITAL } \\
\text { IMPROVEMENT PLAN }\end{array}$} \\
\hline TASK & SCOPE OF WORK & STATUS & EST. COST & SCHEDULE \\
\hline 1 & $\begin{array}{l}\text { Install } 800 \text { feet slip liner from MH39 to MH37, and at various } \\
\text { roots intrusion spots + CCTV + complete System Condition } \\
\text { Assessemnt by Consultant }\end{array}$ & COMPLETED & $750 \mathrm{~K}$ & FY08 \\
\hline 2 & $\begin{array}{l}\text { Install cover to prevent sediment entry at open manhole near } \\
\text { MH } 21 .\end{array}$ & COMPLETED & $25 \mathrm{~K}$ & FY09 \\
\hline 3 & Install sewer cover locks and signs. & COMPLETED & $25 \mathrm{~K}$ & FY09 \\
\hline 4 & Perform engineering design for new sewer line on the east site & COMPLETED & $100 \mathrm{~K}$ & FY09 \\
\hline 5 & Modify sewer sampling facility at the Sewer Outfall & PENDING & $150 \mathrm{~K}$ & FY10 \\
\hline 6 & $\begin{array}{l}\text { Conduct investigations and testing to identify measures to } \\
\text { control copper source. }\end{array}$ & PENDING & $100 \mathrm{~K}$ & FY10 \\
\hline 7 & Install new manhole at MH23 junction. & IN PLANNING & $150 \mathrm{~K}$ & FY11 \\
\hline \multirow[t]{2}{*}{8} & Install new line on the east site from B929 to MH47. & IN PLANNING & $400 \mathrm{~K}$ & FY12 \\
\hline & Subtotal of high priority work & & $1,700 \mathrm{~K}$ & \\
\hline 9 & $\begin{array}{l}\text { Repair lateral connections along line from MH21 to MH29. } \\
\text { (B911 to B910) }\end{array}$ & IN PLANNING & $250 \mathrm{~K}$ & FY13 \\
\hline 10 & $\begin{array}{l}\text { Repair lateral connections along line from MH29 to MH31. } \\
\text { (B914 to B916) }\end{array}$ & IN PLANNING & $250 \mathrm{~K}$ & FY14 \\
\hline 11 & $\begin{array}{l}\text { Line replacement to correct low slope line from } \mathrm{MH} 25 \text { to } \mathrm{MH} \\
20 .\end{array}$ & IN PLANNING & $900 \mathrm{~K}$ & FY15 \\
\hline
\end{tabular}




\begin{tabular}{|c|c|c|c|c|}
\hline & subtotal of medium priority work & & $1,400 \mathrm{~K}$ & \\
\hline 12 & Line replacement to correct failed pipe from MH 36 to $\mathrm{MH} 43$. & IN PLANNING & $400 \mathrm{~K}$ & FY16 \\
\hline 13 & $\begin{array}{l}\text { Install slip liner to repair aged line segment from MH4 to } \\
\text { MH5. }\end{array}$ & IN PLANNING & $200 \mathrm{~K}$ & FY17 \\
\hline 14 & $\begin{array}{l}\text { Install slip liner to repair aged line segment from MH1 to } \\
\text { MH15. }\end{array}$ & IN PLANNING & $150 \mathrm{~K}$ & FY17 \\
\hline 15 & $\begin{array}{l}\text { Install slip liner to repair aged line segment from MH17 to } \\
\text { MH18. }\end{array}$ & IN PLANNING & $150 \mathrm{~K}$ & FY17 \\
\hline \multirow[t]{3}{*}{16} & $\begin{array}{l}\text { Install slip liner to repair aged line segment from MH19 to } \\
\text { MH20. }\end{array}$ & IN PLANNING & $200 \mathrm{~K}$ & FY18 \\
\hline & subtotal of low priority work & & $1,100 \mathrm{~K}$ & \\
\hline & FY08-FY18 Total & & $4,200 \mathrm{~K}$ & \\
\hline
\end{tabular}




\section{Overflow Emergency Response Program}

The site's overflow emergency response program is detailed in the operating procedures for emergency spill response by Hazardous Waste Management (OP471787 Management of Hazardous Waste at SNL/CA) and notification by the wastewater program (OP471608 Operating Procedure for Incident Reporting). The following describes key elements of the Response Plan.

Incidences may be reported by telephone to the ES\&H Hotline 4-3724 or the 24 hour security manned Central Alarm System (CAS) 4-2300. The ES\&H Hotline and security personnel have a call list for response to spills. Waste Management program personnel are contacted to respond to the spill. Waste Management personnel may contact maintenance and staff from other ES\&H programs to assist with the spill. All incident calls to the Hotline and CAS are recorded.

Waste Management personnel respond to spill calls according to OP471634 Hazardous Waste Operations for Department 8516. The spill response team and backup team all receive the appropriate training courses and annual refresher training. Training is documented in the corporate TEDS system. The spill response team may also contact appropriate maintenance and ES\&H personnel as needed. The response team completes an Environmental Protection Emergency Response Records Form (Spill Response Records).

For an emergency sanitary sewer overflow incident the Environmental Monitoring Program lead is notified. The Program lead, or designated backup, is responsible for notification to the appropriate regulatory agencies and DOE/SSO according to the Operating Procedure for Incident Reporting OP471608.

The cleanup procedure is to contain and remove all spilled material (plus any washdown water). Visual monitoring is part of the initial response to determine what immediate actions should be taken. After the initial response and documentation of spill volume, an assessment of possible impacts on surface water should be conducted as part of the spill evaluation process.

The incident reporting procedure and spill response triggers an Occurrence Report. The Occurrence Report is documented by the Quality Assurance Department. The Occurrence Reporting program gathers information, analyzes events for causal factors and determines and tracks actions to prevent recurrence.

The Environmental Monitoring Program lead is responsible for reporting SSOs to the SWQCB via the CIWQS SSO electronic reporting database. Reporting requirements are summarized in Operating Procedure for Incident Reporting OP471608. SSOs must be reported within the following time frames:

- Category 1 Spills (greater threat): Submit uncertified report no later than 3 business days after being made aware of the SSO. Submit final certified report within 15 calendar days of the conclusion of SSO response activities. 
- Category 2 Spills (lesser threat): Submit final certified report within 30 calendar days after the end of the calendar month in which the SSO occurred (no initial, uncertified report is required).

For months during which there are no SSOs, a "no spill certification" must be submitted. In addition, the CIWQS collection system questionnaire must be updated annually.

\section{FOG Control Program}

SNL/CA evaluated the site's sanitary sewer system and service area and has determined a FOG Control Program is not necessary. There have been no identified sections of the sewer system subject to grease blockages or in need of cleaning due to grease obstruction. There are no food preparation activities or grease producing facilities on site that would lead to fats or grease being discharged to the sewer.

The Maintenance yard near Building 963 has a wash pad for cleaning vehicles, carts, and equipment. The wash pad, in operation for approximately ten years, drains to the sanitary sewer through an oil water separator. The separator is a Jensen Precast 500 Gallon Sand-Oil Interceptor (see attached figure). Maintenance staff inspect the separator and schedule the clean out annually (typically in October). Prior to pumping the sump out, the Facilities Maintenance plumber will insure all piping from the wash rack drain to the sump is clear. If necessary, the piping will be snaked out. Waste Management collects samples for analysis by a contract laboratory. Upon receiving the sample analysis results, Waste Management contacts the appropriate disposal company contractor and schedules the service.

Through routine and preventative sanitary sewer maintenance and cleaning staff will continue to monitor the sewer system for possible grease obstructions or blockages. If any occur in the future the creation of a FOG control program will be reevaluated.

\section{Design and Performance Provisions}

Required to be developed by August 2, 2010

\section{System Evaluation and Capacity Assurance Plan}

Required to be developed by August 2, 2010

\section{Monitoring and Program Modifications}

Required to be developed by August 2, 2010

\section{Program Audits}

Required to be developed by August 2, 2010 


\section{Communication Program}

Required to be developed by August 2, 2010

\section{Final SSMP Implementation}

Required to be developed by August 2, 2010 


\section{Appendix A Notice of Intent, LRO Form and Data Submitter Form}




\section{Appendix B Sewer System Map}




\section{Appendix C Training Matrices for SNL/CA Plumbing Staff}

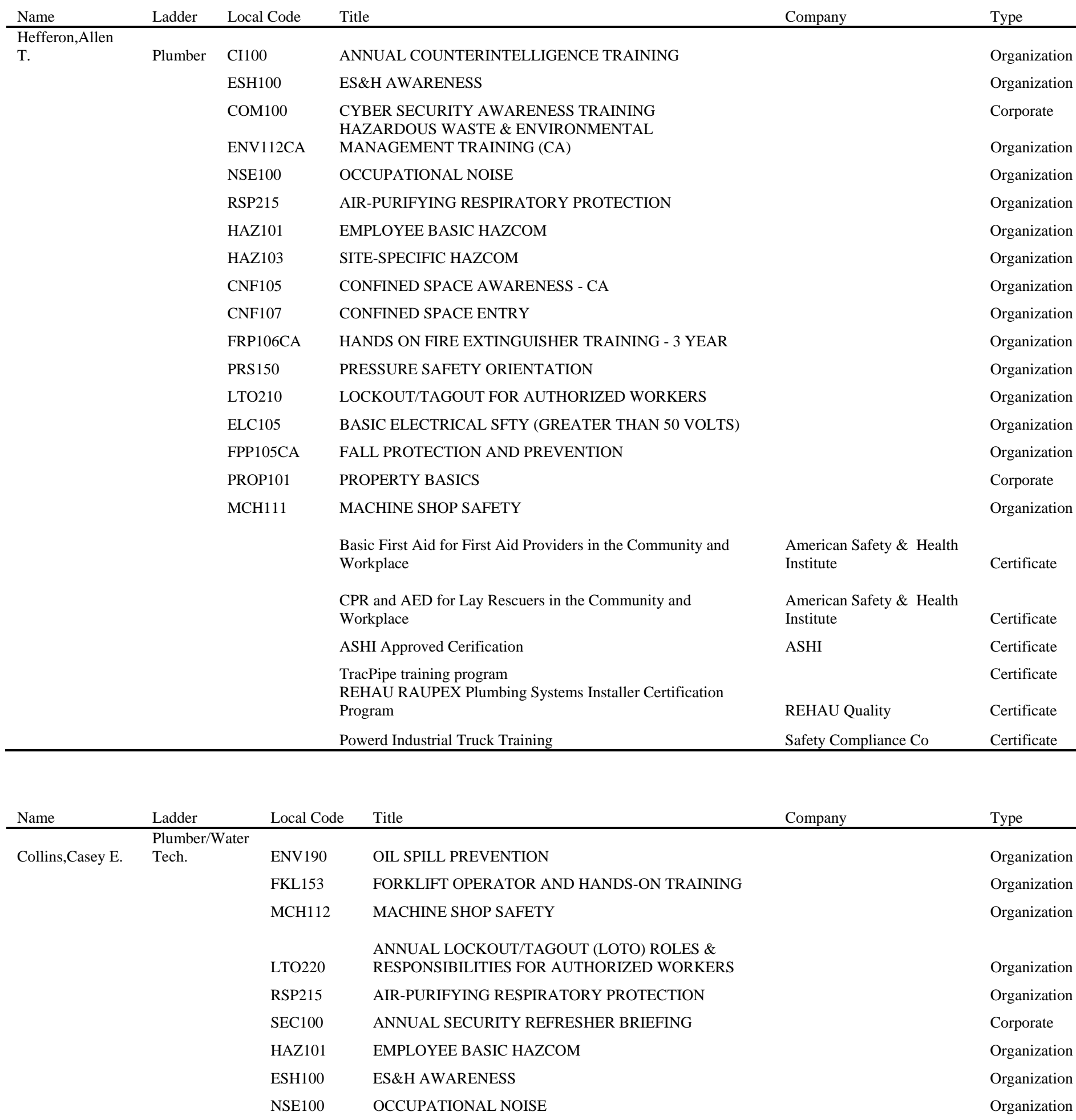




\begin{tabular}{|c|c|c|c|c|c|}
\hline & & HAZ214 & \multicolumn{2}{|l|}{ GENERAL ASBESTOS AWARENESS } & Organization \\
\hline & & COM100 & \multicolumn{2}{|l|}{ CYBER SECURITY AWARENESS TRAINING } & Corporate \\
\hline & & CI100 & \multicolumn{2}{|l|}{ ANNUAL COUNTERINTELLIGENCE TRAINING } & Organization \\
\hline & & MED104CA & \multicolumn{2}{|l|}{ HEART SAVER CPR \& FIRST AID } & Organization \\
\hline & & SEC301 & \multicolumn{2}{|l|}{ CLASSIFIED MATTER TRAINING } & Organization \\
\hline & & HAZ103 & \multicolumn{2}{|l|}{ SITE-SPECIFIC HAZCOM } & Organization \\
\hline & & PRS150R & \multicolumn{2}{|l|}{ PRESSURE SAFETY ORIENTATION REFRESHER } & Organization \\
\hline & & CNF105 & \multicolumn{2}{|l|}{ CONFINED SPACE AWARENESS - CA } & Organization \\
\hline & & CNF107 & \multicolumn{2}{|l|}{ CONFINED SPACE ENTRY } & Organization \\
\hline & & FRP106CA & \multicolumn{2}{|l|}{ HANDS ON FIRE EXTINGUISHER TRAINING - 3 YEAR } & Organization \\
\hline & & FPP105CA & \multicolumn{2}{|l|}{ FALL PROTECTION AND PREVENTION } & Organization \\
\hline & & LTO210 & \multicolumn{2}{|l|}{ LOCKOUT/TAGOUT FOR AUTHORIZED WORKERS } & Organization \\
\hline & & PROP101 & \multicolumn{2}{|l|}{ PROPERTY BASICS } & Corporate \\
\hline & & PKX175 & \multicolumn{2}{|l|}{$\begin{array}{l}\text { DEFENSIVE DRIVER REFRESHER TRAINING } \\
\text { PHCC-GSA Plumbers Unilateral Apprenticeship, } 4 \text { year } \\
\text { Plumbing Apprenticeship \& Training Program \& } \\
\text { Advancement to Journey-Level Status }\end{array}$} & Corporate \\
\hline & & & \multirow[t]{2}{*}{ Training program for Wirsbo AQUAPEX systems } & Wirsbo North America & Certificate \\
\hline & & & & $\begin{array}{l}\text { Western Pacific Truck } \\
\text { School }\end{array}$ & Certificate \\
\hline & & & $\begin{array}{l}\text { Installer Certification for Medical Gas and Vacuum systems } \\
\text { Operator Training Card for conventional fusion of } \\
\text { polyethylene }\end{array}$ & $\begin{array}{l}\text { Dick Mattern Consulting \& } \\
\text { Inspection } \\
\text { ? }\end{array}$ & $\begin{array}{l}\text { Certificate } \\
\text { Certificate }\end{array}$ \\
\hline & & & Welding Certificate & $\begin{array}{l}\text { Testing Services \& } \\
\text { Inspection Inc. }\end{array}$ & Certificate \\
\hline & & & \multicolumn{2}{|l|}{ T-Drill Certificate } & Certificate \\
\hline & & & Backflow Tester Card & $\begin{array}{l}\text { American Water Works } \\
\text { Association }\end{array}$ & Certificate \\
\hline & & & Cooling Towers - Operation /Maintenance & Trane & Certificate \\
\hline Name & Ladder & Local Code & Title & Company & Type \\
\hline \multirow[t]{12}{*}{ Rocha,John B. } & Plumber & MCH111 & \multicolumn{2}{|l|}{ MACHINE SHOP SAFETY } & Organization \\
\hline & & BIO105CA & \multicolumn{2}{|l|}{ BIOSAFETY IN MICROBIOLOGICAL AND } & Organization \\
\hline & & ENV190 & \multicolumn{2}{|l|}{ OIL SPILL PREVENTION } & Organization \\
\hline & & ЕTH2009 & \multicolumn{2}{|l|}{ AWARENESS TRAINING } & Corporate \\
\hline & & CNF105 & \multicolumn{2}{|l|}{ CONFINED SPACE AWARENESS - CA } & Organization \\
\hline & & CI100 & \multicolumn{2}{|l|}{ ANNUAL COUNTERINTELLIGENCE TRAINING } & Corporate \\
\hline & & CNF107 & \multicolumn{2}{|l|}{ CONFINED SPACE ENTRY } & Organization \\
\hline & & LMC230 & \multicolumn{2}{|l|}{ LABOR CHARGING } & Corporate \\
\hline & & LMC330 & \multicolumn{2}{|l|}{ INFORMATION PROTECTION } & Corporate \\
\hline & & LMC190 & \multicolumn{2}{|l|}{ HARASSMENT-FREE WORKPLACE } & Corporate \\
\hline & & SEC100 & ANNUAL SECURITY REFRESHER BRIEFING & & Corporate \\
\hline & & LTO220 & $\begin{array}{l}\text { ANNUAL LOCKOUT/TAGOUT (LOTO) ROLES \& } \\
\text { RESPONSIBILITIES FOR AUTHORIZED WORKERS }\end{array}$ & & Organization \\
\hline
\end{tabular}




\begin{tabular}{|c|c|c|c|}
\hline RSP215 & AIR-PURIFYING RESPIRATORY PROTECTION & & Organization \\
\hline COM100 & CYBER SECURITY AWARENESS TRAINING & & Corporate \\
\hline LMC100 & INSIDER TRADING & & Corporate \\
\hline ESH100 & ES\&H AWARENESS & & Corporate \\
\hline NSE100 & OCCUPATIONAL NOISE & & Organization \\
\hline PROP101 & PROPERTY BASICS & & Corporate \\
\hline SEC301 & CLASSIFIED MATTER TRAINING & & Organization \\
\hline FPP105CA & FALL PROTECTION AND PREVENTION & & Organization \\
\hline HAZ101 & EMPLOYEE BASIC HAZCOM & & Organization \\
\hline HAZ103 & SITE-SPECIFIC HAZCOM & & Organization \\
\hline FRP106CA & HANDS ON FIRE EXTINGUISHER TRAINING - 3 YEAR & & Organization \\
\hline FKL153R & FORKLIFT OPERATOR TRAINING REFRESHER & & Organization \\
\hline PRS150R & PRESSURE SAFETY ORIENTATION REFRESHER & & Organization \\
\hline PRS250R & ADVANCED PRESSURE SAFETY REFRESHER & & Organization \\
\hline LTO210 & LOCKOUT/TAGOUT FOR AUTHORIZED WORKERS & & Organization \\
\hline \multirow[t]{9}{*}{ PRS115R } & CRYOGEN SAFETY REFRESHER & & Organization \\
\hline & Oil Analysis I & Noria Corporation & Certificate \\
\hline & Backflow Prevention Assembly General Tester & $\begin{array}{l}\text { American Water Works } \\
\text { Association }\end{array}$ & Certificate \\
\hline & $\begin{array}{l}\text { Backflow Prevention Assembly Repair and Maintenance } \\
\text { Technician }\end{array}$ & $\begin{array}{l}\text { University of Florida - } \\
\text { TREEO Center }\end{array}$ & Certificate \\
\hline & Plumbing Year One & $\begin{array}{l}\text { Construction Craft Training } \\
\text { Center }\end{array}$ & Certificate \\
\hline & Plumbing Year Two & $\begin{array}{l}\text { Construction Craft Training } \\
\text { Center }\end{array}$ & Certificate \\
\hline & Plumbing Year Three & $\begin{array}{l}\text { Construction Craft Training } \\
\text { Center }\end{array}$ & Certificate \\
\hline & Plumbing Year Four & $\begin{array}{l}\text { Construction Craft Training } \\
\text { Center }\end{array}$ & Certificate \\
\hline & Level I Certified Airborne Ultrasound Inspector & SDT North America & Certificate \\
\hline
\end{tabular}

